\title{
North Carolina: The Development of Party Organizations in a Competitive Environment
}

\author{
Charles Prysby
}

Activists in the two political parties have moved further apart over the past ten years. They already were ideologically distinct in 1991, but since then the Republicans have become even more conservative and the Democrats have moved in a liberal direction. Also, Democratic activists now have a substantially higher percentage of blacks and women in their ranks than was the case in 1991 . Both parties have become somewhat more cohesive than they were in 1991, although both organizations still contain conflict and factions, with the Democrats being somewhat more divided than the Republicans. Among Democrats, the tensions involved in keeping their biracial coalition together can be stressful. Among Republicans, the split between Christian Right conservatives and others is the most obvious deep division. Both parties appear to be stronger organizations now than a decade ago. In particular, the activists report higher levels of organizational activity and the two parties seem fairly evenly matched in grassroots organizational strength at this point in time.

\section{Introduction}

North Carolina, like the rest of the South, has moved from a state in which the Democratic Party dominated electoral politics to a state with genuine two-party competition. The emergence of a competitive balance in elections has been accompanied by the development of stronger party organizations, particularly at the state level. At the local level, party development has been less dramatic and more uneven, but both parties maintain active county organizations across the state. These grassroots organizations remain important even in an era of candidate-centered and media-oriented campaigns. Surveys of the political party activists who were leaders in these county organizations were conducted in 1991 and 2001, and the results reveal interesting patterns of change and continuity between and within the parties over the past ten years. Before examining these data, it will be useful to briefly review developments in the political party system as a background for the survey results.

CHARLES PRYSBY is a professor of political science at the University of North Carolina at Greensboro. The author thanks the following former students for their work as research assistants during various stages of this project: Brian Clark, Kelly Dunn, Gabriella Kohlmeier, Katie McCarthy, and Amanda Osborne.

The American Review of Politics, Vol. 24, Summer, 2003: 145-164

(C)2003 The American Review of Politics 


\section{Development of Political Parties in North Carolina}

The past forty years have been particularly important for the development of political parties in North Carolina. In 1960, the state was still dominated by the Democratic Party in all major elections, from the presidential and congressional races at the top, through state government elections, down to local elections. Forty years later, party competition was intense at most levels. Changes in party organizations during this period are even more dramatic. Little in the way of permanent party organization existed at the state level in 1960, but by 2000 both state parties had established substantial party organizations.

\section{Electoral Patterns, 1960-2000}

The last forty years represent an extended period of secular realignment in North Carolina. Gradually, and sometimes unevenly, the state moved from Democratic dominance to two-party competition. Table 1 presents election results for a variety of offices in North Carolina from 1960 through 2000. The pattern of Republican growth that we see in that table has many characteristics that are common to change in the South as a whole: initial success in presidential elections, followed by success in prominent statewide offices, such as U.S. senator or governor, and then followed by success in congressional and state legislative races. Republicans first carried the state in a presidential election in 1968 and in a senatorial or gubernatorial election in 1972. Not until 1994 did Republicans manage to capture a majority of U.S. House seats and a majority of seats in at least one house of the state legislature. Although the 1994 successes were not fully duplicated in subsequent elections, the Republicans still captured a higher proportion of congressional and state legislative seats in 1998 and 2000 than they had in any election prior to 1994. But while Republicans made clear gains in these legislative races, gains in higher level offices, particularly governor or senator, were not present during the last decade. In fact, Democrats showed significant resiliency in the past several years, defeating an incumbent Republican senator in 1998 and winning an open gubernatorial election in 2000, a year in which the Republican presidential candidate carried the state by a comfortable margin.

North Carolina entered the twenty-first century with a very competitive balance between the parties. Democrats maintained a clear edge in state government. The governor and eight of the nine other state-wide executive officials (the Council of State) were Democrats. Both houses of the state legislature were controlled by the Democrats, albeit by a slim margin in the lower house. Republicans had an edge in the congressional delegation, as 
Table 1. Republican Strength in North Carolina, 1960-2000

\begin{tabular}{|c|c|c|c|c|c|c|}
\hline Year & $\begin{array}{c}\text { Percent of } \\
\text { Presidential } \\
\text { Vote }\end{array}$ & $\begin{array}{c}\text { Percent of } \\
\text { Gubernatorial } \\
\text { Vote }\end{array}$ & $\begin{array}{c}\text { Percent of } \\
\text { U.S. Senate } \\
\text { Vote }\end{array}$ & $\begin{array}{l}\text { Percent of } \\
\text { U.S. House } \\
\text { Delegation }\end{array}$ & $\begin{array}{l}\text { Percent of } \\
\text { State House } \\
\text { Delegation }\end{array}$ & $\begin{array}{c}\text { Percent of } \\
\text { State Senate } \\
\text { Delegation }\end{array}$ \\
\hline 1960 & 47.9 & 45.5 & 38.6 & 8.3 & 12.5 & 4.0 \\
\hline 1962 & & & 39.6 & 18.2 & 17.5 & 4.0 \\
\hline 1964 & 43.8 & 43.4 & & 18.2 & 11.7 & 2.0 \\
\hline 1966 & & & 44.4 & 27.3 & 21.7 & 14.0 \\
\hline 1968 & $57.5^{*}$ & 47.3 & 39.4 & 36.4 & 24.2 & 24.0 \\
\hline 1970 & & & & 36.4 & 20.0 & 14.0 \\
\hline 1972 & 70.6 & 51.3 & 54.0 & 36.4 & 29.2 & 30.0 \\
\hline 1974 & & & 37.3 & 18.2 & 7.5 & 2.0 \\
\hline 1976 & 44.4 & 34.3 & & 18.2 & 5.0 & 6.0 \\
\hline 1978 & & & 54.5 & 18.2 & 11.7 & 12.0 \\
\hline 1980 & 51.1 & 37.7 & 50.3 & 36.4 & 20.0 & 20.0 \\
\hline 1982 & & & & 18.2 & 15.0 & 12.0 \\
\hline 1984 & 62.0 & 54.4 & 51.9 & 45.5 & 31.7 & 24.0 \\
\hline 1986 & & & 48.2 & 27.3 & 30.0 & 20.0 \\
\hline 1988 & 58.2 & 56.1 & & 27.3 & 38.3 & 26.0 \\
\hline 1990 & & & 52.6 & 36.4 & 30.8 & 28.0 \\
\hline 1992 & $50.5^{* *}$ & 45.1 & 52.2 & 33.3 & 34.4 & 22.0 \\
\hline 1994 & & & & 66.7 & 55.8 & 48.0 \\
\hline 1996 & $52.5 * * *$ & 43.3 & 53.4 & 50.0 & 50.8 & 42.0 \\
\hline 1998 & & & 47.9 & 58.3 & 45.0 & 30.0 \\
\hline 2000 & 56.5 & 47.1 & & 58.3 & 48.3 & 30.0 \\
\hline \multicolumn{7}{|c|}{$\begin{array}{l}\text { Notes: The vote is calculated as a percentage of the two-party vote. *In 1968, Republican Richard } \\
\text { M. Nixon won the state with } 40 \text { percent of the vote; Democrat Hubert H. Humphrey and American } \\
\text { Independent George C. Wallace received } 29 \text { and } 31 \text { percent, respectively. **In 1992, Republican } \\
\text { George W. Bush won the state with } 43 \text { percent of the vote; Democrat Bill Clinton and independent } \\
\text { Ross Perot received } 43 \text { and } 14 \text { percent, respectively. ***In 1996, Republican Robert Dole won the } \\
\text { state with } 49 \text { percent of the vote; Democrat Bill Clinton and Reform Party candidate Ross Perot won } \\
44 \text { and } 7 \text { percent, respectively. The last three columns give the percent Republican following the } \\
\text { specified election (e.g., after the } 1998 \text { election, Republicans held } 30 \text { percent of the state senate } \\
\text { seats). } \\
\text { Sources: America Votes (Washington, DC: Congressional Quarterly, 1960-1990) and Statistical } \\
\text { Abstract of the United States (Washington, DC: Government Printing Office, 1960-1992), various } \\
\text { editions. The 1992-2000 figures were provided by the North Carolina Board of Elections. }\end{array}$} \\
\hline
\end{tabular}

they held one of the two U.S. Senate seats and seven of the twelve U.S. House seats. Presidential elections were the most favorable to the Republicans; they won all three of the presidential elections held since 1990, each time by a margin of victory greater than in the previous election. Although the 1980s were a competitive decade in North Carolina, the 1990s were even more so, especially further down the ballot. This deeper and more pervasive 
two-party competition over the past decade may help to explain some of the changes in the party organizations between 1991 and 2001.

\section{Development of State Party Organizations}

The development of political party organizations in North Carolina parallels the emergence of a competitive two-party system. Republican Party organizational strength naturally was weak until the party began to enjoy electoral success. The growth of Republican voting has been matched by increased development of the party organization. Democratic Party organization similarly developed during this period, in large part because increased electoral competition made a strong and viable state party organization an important asset. The strength of state party organization can be measured by examining several key indicators: headquarters, staffing, budget, and activities. Over the past three decades, both parties established more visible state headquarters that were better staffed and funded, especially in election years, and engaged in a wider range of activities. They also have attempted to establish and maintain strong county party organizations, although there naturally has been considerable variation in the vitality of the county organizations for both parties.

In the early 1970s, both parties maintained minimal state headquarters, in each case consisting of only a small staff in rented office space. By the early 1980 s, more substantial state headquarters were established. Both parties now owned their state headquarters building, and both had significantly expanded their staff and budget. For example, in 1984 the Democratic state party staff had grown to about twelve individuals and another fourteen were in the Unity Campaign and the Victory Fund, two parallel campaign organizations. The state party budget in 1984 was around \$2 million, including the Unity Campaign and Victory Fund (Prysby 1997). Similar developments occurred in the Republican state headquarters, where the annual budget increased from $\$ 150,000$ in 1980 to $\$ 1.6$ million in 1988 , and the staff grew to nine full-time individuals, including such positions as political director, finance director, and communications director (Prysby 1997). There also was a separate organization (Victory ' 88 ), with a sizable staff and budget, to support the 1988 campaign efforts.

In the 1990s the party organizations remained well financed and active (Prysby 1997). In 1996, for example, the Republican state party had ten fulltime staff members and a budget of $\$ 2$ million, plus another $\$ 3$ million in the coordinated "Victory ' 96 " campaign, directed by the state party. Even in 1999, a year in which no state or congressional elections were held, the headquarters had six full-time staff and an operating budget of approximately $\$ 1$ million. Democratic Party state headquarters staff and budget kept pace with the Republican in the 1990s. In 1994, an off-year election with no 
state-wide race on the ballot, the Democratic state party had a staff of fourteen and a budget of $\$ 1.3$ million, and in 1998 the staff included eleven fulltime individuals and the budget exceeded $\$ 1.5$ million. Even in 1999, the state party headquarters had seven full-time staff members and an operating budget of approximately $\$ 750,000$.

Both parties have attempted to establish grassroots organizations in the counties. Strong county-level Republican organization is a recent phenomenon. Prior to the mid-1980s the party lacked much of a state-wide grassroots organization, although it had been strong in selected areas. By the mid1990 s, over 90 percent of the counties had at least a minimally functioning Republican party organization, meaning that the party held a county convention as scheduled and engaged in ongoing activity during the year (Prysby 1997). Most of the counties now establish a temporary party headquarters during election years, although very few maintain a permanent headquarters. The level of party activity varies greatly from county to county. Some have highly active organizations, which raise money, send out regular newsletters, and hold a variety of meetings and events. Others, perhaps the majority, display a more modest activity level. There are 100 counties in the state, many of them very small, and the level of county party organization must be judged from that perspective.

Democratic county-level organization has a longer history of activity, in part because so many local officials were Democrats in earlier years. However, grassroots organization appears to have deteriorated somewhat during the 1980s and 1990s. Local fund raising and attendance at county conventions dropped, for example (Prysby 1997). The current state of Democratic Party county organization is roughly similar to that of the Republican Party. Few counties have a permanent headquarters; almost all establish a temporary headquarters in election years. County party activity varies greatly. Most have at least a modest level of activity; perhaps onethird could be considered highly active.

\section{Grassroots Party Activists, 2001 and 1991}

Grassroots party activists in North Carolina were surveyed in 2001 and 1991 as part of the Southern Grassroots Party Activists Projects. In both years, the focus was on elected members of the county executive committee and precinct chairs, although the sampling frames differed somewhat for the two years and for the two parties. A detailed description of the 2001 sample is in the introduction to this issue. The 1991 sample was similar (Prysby 1992). Since the 1991 data have already been extensively analyzed, the following analysis concentrates on the results for 2001, but the 1991 results are used to identify continuities or discontinuities over the ten years. 
Table 2. Demographic Profiles of North Carolina Political Party Activists

\begin{tabular}{|c|c|c|}
\hline & Democrats & Republicans \\
\hline Gender: $\%$ males & 50 & 61 \\
\hline Race: \% white & 74 & 94 \\
\hline Income: $\% \$ 75,000+$ & 38 & 40 \\
\hline Education: $\%$ college degree & 63 & 65 \\
\hline $\begin{array}{l}\text { Religion: } \% \text { mainline Protestant } \\
\\
\% \text { evangelical Protestant } \\
\% \text { black Protestant } \\
\% \text { other or none }\end{array}$ & $\begin{array}{l}39 \\
27 \\
22 \\
12\end{array}$ & $\begin{array}{r}46 \\
38 \\
2 \\
14\end{array}$ \\
\hline Church attendance: $\%$ weekly or almost weekly & 69 & 70 \\
\hline Importance of religion: \% great deal & 56 & 63 \\
\hline Born-again Christian: \% yes & 53 & 64 \\
\hline Christian right: $\%$ feeling close & 12 & 45 \\
\hline $\begin{array}{ll}\text { Age: } & \% \text { over } 50 \\
& \% \text { over } 65\end{array}$ & $\begin{array}{l}63 \\
27\end{array}$ & $\begin{array}{l}57 \\
25\end{array}$ \\
\hline $\begin{aligned} & \text { Years lived in state: } 10 \text { or less } \\
& 25 \text { or less }\end{aligned}$ & $\begin{array}{r}6 \\
15\end{array}$ & $\begin{array}{l}14 \\
32\end{array}$ \\
\hline Regional background: \% from North & 14 & 26 \\
\hline$(\mathrm{N})$ & $(416)$ & $(307)$ \\
\hline
\end{tabular}

\section{Social and Demographic Characteristics}

There are some clear differences between Democratic and Republican activists in their social and demographic characteristics, which are presented in Table 2. The two most striking differences involve gender and race. Democratic activists include a much larger number of women and blacks than do Republican activists. These differences among activists reflect differences within the electorate. In the 2000 presidential election, for example, George W. Bush ran much better among men and whites in North Carolina (Prysby 2002a). While the differences among activists appear to be what we would expect, it is worth noting that racial differences were much 
smaller and gender differences nonexistent in 1991 (Prysby 1992). Republican activists changed little in their racial and gender profile over this tenyear period, but Democrats changed considerably, going from around 85 percent white and two-thirds male in 1991 to about 75 percent white and one-half male in 2001.

Democratic activists also are more likely than Republicans to have grown up in the South and to be long-time residents of the state. This fact reflects the considerable contribution that in-migration to the region has made to southern Republican party organizations (Feigert and Todd 1998a; Moreland 1990b). While Republicans are more likely to have grown up in the North and more likely to have lived in the state for a shorter period of time, the vast majority of Republican activists are not recent Northern immigrants; about three-fourths of the Republican activists grew up in the South and about two-thirds have lived in the state for over twenty-five years. Thus, while party differences exist on these dimensions, they may not be very significant.

While clear differences exist in some areas, similarities prevail in other ways. For example, both groups of activists are very similar in socioeconomic status, a pattern that existed in 1991 as well (Prysby 1995). Given the strong relationship between SES and political participation and the fairly weak relationship between partisanship and SES, this finding probably is unremarkable. It also is quite possible that if we had detailed data on the occupations of the activists, we might find party differences among activists. Democratic activists might be more likely to be teachers, government workers, or attorneys; Republicans might be more likely to be employed in private industry or to be self-employed entrepreneurs.

Differences between Democratic activists in age also are small, and in this case the 2001 pattern represents a significant change from 1991, when Democratic activists were much older on average than Republicans (Prysby 1992). Between 1991 and 2001, Democratic activists became a younger group overall; about 63 percent were over 50 years old in 2001, compared to 70 percent in 1991. Republicans moved in the opposite direction, with only 47 percent over 50 in 1991 but 57 percent over 50 in 2001. The change over these ten years seems particularly significant for Democrats. Despite the rise of the Republican Party in the state, the Democratic Party has been able to attract younger activists into the county organizations, and the party clearly is not dominated at the grassroots by a set of elderly activists.

Religious differences also are minimal. Both groups of activists are nearly 90 percent Protestant, which reflects the prevalence of Protestant denominations in North Carolina. These Protestant denominations can be divided into mainline, evangelical, and black churches (the first two categories designating denominations that are predominantly white). Democrats 


\section{2 | Charles Prysby}

have far more black Protestants, but among the white Protestants, the division between mainline and evangelical churches is similar for both parties, which seems somewhat surprising, given the support that Republican candidates receive from white evangelicals in the South. It also is interesting to note that an analysis of the measures of religiosity - church attendance, importance of religion in one's daily life - indicate that Democratic activists are about as religious as are Republicans. This result also seems surprising, given the differences between the parties on some key issues that are related to religion. However, when it comes to feelings toward the Christian Right, Democratic and Republican activists diverge substantially, a difference that is consistent with the findings of earlier studies of religion in southern politics (Baker 1990; Baker, Steed, and Moreland 1998).

Religious differences exist between white and black Democratic activists. White Democrats are a fairly religious group - over 60 percent attend church regularly, and nearly half say that religion is very important in their lives-but blacks are much more so, as about 90 percent of them attend church regularly and almost 90 percent say that religion is very important in their lives. A similar schism exists in the Republican Party between activists who feel close to the Christian Right and those who not. Those who do not feel close are significantly less religious than those who do, although they still are fairly religious overall.

The survey also collected information about organizations and groups in which the activists had been involved (Prysby 2002b). Democrats are more likely than Republicans to have been active in teacher's organizations, labor unions, environmental groups, civil rights groups, and women's rights groups - all groups that are associated with the Democratic Party. However, Democratic activists also are more likely than Republican activists to report having been active in business groups and civic organizations, groups not clearly associated with the Democratic Party. Participation in church groups is about even for the two parties, which fits with the above findings regarding religious differences. It appears that Democrats have a significantly higher overall level of participation in groups and organizations.

\section{Ideological and Issue Orientations}

Realignment in the South has involved changes among voters and among party organizations and has been driven by both transformation and replacement. The same sources of new voters also are sources of new party

activists. Republican party strength has increased through the addition of party activists from the ranks of new members of the electorate (both northern migrants and younger voters), from the conversion of former Democrats, and from the mobilization of Republicans previously not disposed to be 
involved in the party organization. Democrats have added new activists as well. We would expect these activists to be drawn to their parties because of ideological compatibility, and the result should be greater party distinctiveness and increased party cohesion on policy issues (Nesbit 1988; Clark, Bruce, Kessel, and Jacoby 1991). Earlier studies of southern party activists emphasized the ideological gap between Democrats and Republicans (Brodsky and Cotter 1998; McGlennon 1998b; Moreland 1990a). Here we are able to see if there has been further party polarization in recent years.

North Carolina party activists are clearly divided by ideology. Republicans activists overwhelmingly identify as conservatives. Over 90 percent are conservatives, and over 50 percent call themselves very conservative. Democrats are closer to the ideological center, with nearly one-third identifying as moderates. Almost 60 percent identify themselves as liberal, but fewer than one-fifth claim to be very liberal. This sharp ideological distinction is even greater than the clear distinction that existed in 1991. Republican activists are more conservative than they were a decade ago, when only about 40 percent called themselves very conservative (Prysby 1992). Democratic activists have become more liberal, or at least less conservative. In 1991, about one-fifth of the Democratic activists identified themselves as conservatives (Prysby 1992). In 2001 this figure dropped to one in eight. Similarly, only 10 percent of Democratic activists were very liberal in 1991, a figure that nearly doubled by 2001 .

Given the sharp and growing ideological divisions between Democratic and Republican political party activists, we would expect to find clear partisan differences on specific issues of public policy. Table 3 presents mean scores for thirrteen issue items, which have been grouped into three sets: (1) economic issues, involving taxation and social welfare policies; (2) equality issues, involving civil rights and other discrimination issues; and (3) social issues, involving a variety of domestic non-economic issues. The overall pattern corresponds to the ideological differences discussed above. Republican activists have a mean score of over three (on a four-point scale, with four being the most conservative position) on all but two items, both of which involve civil rights issues. Democrats are not as strongly liberal across the board. They have mean scores of under two for only eight of the items.

On economic issues, Democrats are significantly more liberal than Republicans. For example, on the general question of whether the government should provide fewer services in order to reduce spending, Democrats have a mean score of 1.72, compared to 3.07 for Republicans, a difference of over one full point. The other items in this group also have party differences of over one point, with the question about the desirability of a flat tax producing the greatest difference in mean scores between the two parties. 
154 | Charles Prysby

Table 3. Issue Orientations of North Carolina Political Party Activists

\begin{tabular}{|c|c|c|c|}
\hline Issue & Democrats & Republicans & Difference \\
\hline \multicolumn{4}{|l|}{ Economic Issues } \\
\hline Government services and spending & 1.72 & 3.07 & 1.35 \\
\hline Guaranteed job and living standard & 2.45 & 3.50 & 1.05 \\
\hline Regulation of health care & 1.96 & 3.16 & 1.20 \\
\hline Flat tax system & 1.28 & 3.14 & 1.86 \\
\hline \multicolumn{4}{|l|}{ Civil Rights and Equality Issues } \\
\hline Minority aid & 1.78 & 2.72 & .94 \\
\hline Affirmative action & 2.84 & 3.60 & .76 \\
\hline Improve the situation of women & 1.71 & 2.70 & .99 \\
\hline Gay job discrimination & 2.11 & 3.12 & 1.01 \\
\hline \multicolumn{4}{|l|}{ Social Issues } \\
\hline Abortion & 1.57 & 3.02 & 1.45 \\
\hline Death penalty & 2.33 & 3.12 & .89 \\
\hline School prayer & 2.88 & 3.48 & .60 \\
\hline School vouchers & 1.44 & 3.14 & 1.70 \\
\hline Handgun control & 1.72 & 3.27 & 1.55 \\
\hline$(\mathrm{N})$ & $(416)$ & $(307)$ & \\
\hline \multicolumn{4}{|c|}{$\begin{array}{l}\text { Note: Entries in the first two columns are mean scores. The scale for each item runs from } 1.0 \text { to } 4.0 \\
\text { A lower score indicates a more liberal position. The entries in the third column are the Republicar } \\
\text { mean score minus the Democratic mean score. The number of respondents from each party is in } \\
\text { parentheses. The Ns for individual issue items are sometimes lower, due to missing data. }\end{array}$} \\
\hline
\end{tabular}

Although Democratic and Republican activists have similar SES profiles, at least in terms of education and income, they differ greatly on basic economic policy issues.

Questions of equality also divide the two groups of activists. The expected party divisions are present, although the differences are less than what we find for the economic issues. Given that equality issues, both racerelated and other, can be very emotionally charged and that some of them have played a prominent role in recent state-wide campaigns, it is at least somewhat surprising to see that the party differences among activists are smaller for these items than they are for economic issues. One item warrants particular attention here. On an affirmative action question involving preferential hiring of blacks, Republicans are strongly opposed, as we would expect, but Democrats are rather ambivalent overall. The ambivalence among Democrats reflect intra-party racial divisions on this issue, divisions that may be greater now than in 1991 because of the previously discussed 
increased presence of black activists in the Democratic Party. Since affirmative action questions are currently among the most salient civil rights issues, these findings indicate that such issues could divide the biracial coalition that is essential to Democratic success in North Carolina.

On social issues, there are large differences between Democratic and Republican activists on some issues but small differences on others. Differences on abortion are among the largest to be found in Table 3. Differences on handgun control are equally large, even though gun control has not been a particularly salient issue in recent state elections. The question of publicly funded school vouchers, which was a salient issue in the 2000 gubernatorial election, is a third social issue that sharply divides the parties. On two other issues, the death penalty and school prayer, Republican activists hold clearly conservative positions, but Democrats fail to be clearly liberal. On both of these items, the mean score for Democrats falls in the middle of the scale. Thus, there are some social issues where a significant number of Democrats hold fairly conservative positions, which might be another potential source of intra-party tensions. However, these issues are not necessarily that divisive. For example, while it has its opponents, capital punishment enjoys widespread support throughout the state and has not been the subject of serious conflict within or between parties.

Comparing the 2001 analysis of issue orientations with the 1991 analysis is difficult. Many of the questions asked in 2001 were not asked in 1991. Three items, one from each set of issues, were asked in both years, and an analysis of these items yields some interesting results (Prysby 1995). On the question of reducing government services and spending, Republicans held very similar positions in both years, but Democrats were clearly more liberal in 2001 than they were in 1991 (a 2001 mean score of 1.72, compared to 2.05 in 1991). Both Democrats and Republicans were more liberal in 2001 on the question of the desirability of government aid for blacks and other minorities, with the difference being somewhat greater for Democrats. Finally, Democrats moved in a liberal direction on the abortion issues between 1991 and 2001, while the Republicans moved in a conservative direction. In 1991, abortion stood out as the most divisive issue among Republicans, but there was far less intra-party division on this issue among Republicans in 2001. The greater inter-party differences on these issues in 2001, as compared to 1991, reflect the changes in ideological orientations discussed above. The leftward movement of Democratic activists is consistent with the greater representation of women and blacks discussed earlier, as both of these groups tend to be more liberal than white male activists.

Another set of issue items asked activists whether they favored increasing, decreasing, or holding constant government spending in a number of specific areas. Table 4 presents data for these items, reporting the percent 
Table 4. Orientation on Spending Issues for North Carolina Political Party Activists

\begin{tabular}{lccc}
\hline Spending Item & Democrats & Republicans & Difference \\
\hline Defense & 11 & 83 & 72 \\
Environment & 63 & -18 & -81 \\
Schools & 79 & -8 & -87 \\
Crime & 47 & 26 & -21 \\
Social Security & 64 & 7 & -57 \\
Health care & 83 & -7 & -90 \\
Welfare programs & -2 & $(307)$ & -76 \\
(N) & $(416)$ & \\
Note: Entries in the first two columns are the percentage favoring increased spending minus the \\
percentage favoring decreased spending. The entries in the third column are the Republican score \\
minus the Democratic score. The number of respondents from each party is in parentheses. The Ns \\
for individual items are sometimes lower, due to missing data. \\
\hline
\end{tabular}

who favor increasing spending minus the percent who favor decreasing spending. Positive scores indicate a surplus of increased spending responses over decreased spending responses; negative scores indicate the opposite. These questions were not asked in 1991, so we cannot examine change in these attitudes over the past ten years.

Republicans are overwhelmingly in favor of increasing defense spending. Democrats have more mixed views, with a slightly larger number favoring increasing spending than decreasing spending. On all the domestic spending items, Democrats are in favor of spending more than Republicans. In some cases, such as on education spending, the pattern is that Democratic activists overwhelmingly favor spending more money, while Republicans hold fairly mixed views. On spending to fight crime, activists in both parties favor spending more, but by a wider margin among Democrats. A third pattern characterized responses to welfare spending; Republicans overwhelmingly want to reduce spending, while Democrats are evenly divided. But while the absolute scores vary from one domestic spending question to the next, in each case there is a sizable difference between the two groups of activists, a difference that in most cases is over 70 percentage points. To illustrate the magnitude of these differences, we can examine more closely attitudes on spending more on social security, an issue where the partisan difference was "only" 57 percentage points. On this issue, about two-thirds of the Democratic activists favor increased spending, with almost all the remaining activists supporting spending at the same level. Fewer than onefourth of Republican activists desire higher spending on social security, 
about 60 percent favor keeping spending the same, and one-sixth support lower spending.

The large and often growing differences between Democratic and Republican activists on issues of public policy raise questions about elitemass ideological differences. A number of studies of party activists, both nationally and in the South, indicate that activists often display substantially more ideological polarization than what we find in the electorate (Breaux, Shaffer, and Cotter 1998; Jackson, Brown, and Bositis 1982; Maggiotto and Wekkin 2000). While we lack the survey data on the North Carolina electorate to fully answer this question, it appears that these elite-mass differences exist in the state. For example, in the 2000 gubernatorial election, only around 60 percent of those voting Republican called themselves conservatives, and only about 30 percent of those voting Democratic identified themselves as liberals (Prysby 2002a).

Given the substantial ideological and issue divisions between Democratic and Republican activists, it is not surprising to find that they differ greatly in their feelings toward the national and state parties. Republicans tend to be warmer toward their own party and colder toward the opposition than is the case for Democrats. Democratic activists feel significantly warmer toward their state party than they do toward their national party, a pattern that is far less pronounced among Republicans. This difference is most likely a reflection of the more moderate ideological orientations of Democratic activists in the state. Although the distinction between national Democrats and North Carolina Democrats is less salient than it used to be, it still exists. In fact, even Republicans differed in their reactions to the Democratic national and state parties.

It also is worth noting that Republican activists are more purist than their Democratic counterparts. The distinction here is best conceptualized as a continuum on which "purist" and "pragmatist" are end points (Prysby 1998; Roback 1975; Soule and Clarke 1970). Purists emphasize ideological purity, even at the expense of electoral success; pragmatists readily compromise on issues for the sake of electoral victory. This concept was measured by a four-point index constructed from four items (Prysby 2002b). Democratic activists have a mean score of 2.43 , compared to 2.61 for Republicans (1.0 was the most pragmatic score possible; 4.0 the most purist). The greater purism of Republican activists is consistent with the previous findings on their ideological and issue orientations. Still, while Republicans are more purist on average, they still are far from the end-point of the scale, so it would not be correct to characterize them as extremely purist overall. 


\section{Factionalism}

In a two-party system, each major party must appeal to a broad group of voters to win, usually having to forge a coalition from groups that disagree on some key questions. In such a situation, factions are likely to form within the party, and conflict between these factions for control over the party may be significant. The above analysis of the issue orientations of activists indicates that differences do exist within each party. In 1991, North Carolina ranked fairly high among southern states in the degree of its party factionalism (McGlennon 1998a).

We can examine factionalism by looking at the perceptions of party activists, who were asked about the level of factionalism in their state and county parties. A slim majority of activists in both parties characterized factionalism in their state and county parties as low. A sizable minority (46 percent of Democrats and 40 percent of Republicans) perceived factionalism to be high, but most reported moderately, rather than very, high factionalism in their state or county party. The questions about factionalism were asked in a somewhat different format in 1991, complicating our efforts to make comparisons across time, but it appears that activists perceived more factionalism in 1991 than in 2001 (Prysby 1992). The decline in perceptions of factionalism may be a result of the growth in the ideological homogeneity of the party activists that has already been discussed.

A variety of sources of factionalism were identified by the activists. Democrats in particular mentioned regional divisions or urban-rural divisions as a basis for factionalism. This most likely refers to the division between eastern and more rural white Democrats, who tend to be more conservative, and urban Democrats, located predominantly in the central piedmont, who are more moderate or liberal. Democrats also were more likely to report racial issues, spending issues, and tax issues as a source of factionalism than were Republicans, a result that is consistent with the findings reported earlier on issue orientations. Questions of affirmative action and domestic social welfare programs are the types of issues that can divide the Democratic biracial coalition (Hadley and Stanley 1998). Abortion was cited about equally by activists in both parties as a cause of factionalism, which is a big change from 1991, when Republicans were far more divided by this question. Republicans were relatively more likely to cite ideology as a basis of factionalism, although this seems somewhat odd, given the earlier analysis showing that Republicans are more consistently conservative than Democrats are liberal. What it suggests is that there are divisions between moderately conservative and highly conservative Republican activistsbetween the conservatism of a Jesse Helms versus an Elizabeth Dole, for example. Overall, it appears that factionalism in each party is a result of 
many sources, but that among Democrats it is more likely to be based on geography, economic issues, and racial issues, whereas among Republicans it is more likely to be based on social issues and on party leaders.

\section{Activity Patterns}

Ascertaining the activity levels of these activists will help us understand whether political parties in the South have improved in recent years in organizational strength at the local level (Clark, Lockerbie, and Wielhouwer 1998; Feigert and Todd 1998b). Earlier national studies found that in many ways state and local political party organizations were not in a state of decay, contrary to some popular views (Gibson, Cotter, Bibby, and Huckshorn, 1983 and 1985). In terms of both organizational complexity and programmatic complexity, these studies found improvement, although the changes were uneven across parties and geographical regions (Gibson, Frendries, and Vertz, 1989). We have few studies of the organization development or decline of grassroots parties in the South during the 1990s, so this analysis may shed some light on this area. There are reasons to expect increased county-level organizational activity over the past ten years. Republicans in North Carolina have made a conscious effort to build their county organizations, an organizational development that was of lower priority in earlier years, when the emphasis was on improving the state party organization. Democrats also have been concerned with their county organizations, but from a somewhat different perspective. Their concern has been with a possible deterioration of the local organizations. During the $1980 \mathrm{~s}$, the Democratic county organizations were substantially more active overall than were the Republican organizations, but, as discussed earlier, there has been concern in the party about a decline in organizational vitality at the grassroots level.

Party activists also were asked to identify specific activities in which they engaged in recent elections. In examining responses to this question, it is useful to distinguish the county chairs from other members of the county executive committee. The county chairs hold the most important positions at the local level, and their activity patterns are therefore of particular significance. Table 5 reports participation in various campaign activities for county chairs and other grassroots activists, by party.

There are many similarities between the two parties in activity patterns. The most popular activities in both parties among the members of the executive committee (excluding the county chairs) were distributing campaign literature, distributing campaign posters and signs, and contributing money. Additionally, close to one-half of these activists report helping to organize campaign events, helping to arrange fund-raising events, helping with 
Table 5. Campaign Activities of North Carolina Political Party Activists

\begin{tabular}{lcccc}
\hline & \multicolumn{2}{c}{$\begin{array}{c}\text { Democrats } \\
\text { Chairs }\end{array}$} & $\begin{array}{c}\text { Republicans } \\
\text { Chairs }\end{array}$ & Members \\
\hline Organized canvassing efforts & 29 & 28 & 26 & 20 \\
Organized campaign events & 77 & 47 & 85 & 50 \\
Organized fund-raising activities & 76 & 41 & 81 & 47 \\
Sent mailings to voters & 60 & 42 & 78 & 50 \\
Distributed campaign literature & 83 & 73 & 88 & 69 \\
Organized telephone campaigns & 64 & 37 & 85 & 46 \\
Distributed campaign posters, signs & 92 & 77 & 91 & 79 \\
Contributed money & 77 & 81 & 91 & 86 \\
Conducted voter registration drives & 50 & 31 & 57 & 30 \\
Utilized public opinion surveys & 12 & 9 & 21 & 14 \\
Dealt with media & 62 & 23 & 81 & 28 \\
Helped with campaign websites & 18 & 4 & 22 & 8 \\
(N) & $(66)$ & $(350)$ & $(58)$ & $(248)$ \\
Note: Entries are the percent who said that they engaged in the campaign activity in recent elections. & & & \\
Chairs are county chairs; members are other members of the county executive committee. The num- \\
ber of respondents from each party and position is in parentheses. The Ns for individual items are \\
sometimes lower, due to missing data. \\
Source: Southern Grassroots Party Activists 2001 data; North Carolina sample. \\
\hline
\end{tabular}

mailings to voters, and helping with telephone campaigns. Less popular activities, at least for executive committee members, as opposed to county chairs, include helping to organize door-to-door canvassing, helping to conduct voter registration drives, and dealing with the media. On all these items, the percentages among executive committee members are fairly similar across party lines.

County chairs display a different activity profile than do the other members of the county executive committee. Overall, chairs are more active. The increased activity is particularly great for dealing with the media and for organizing campaign events, fund-raising activities, and voter registration drives - all activities where we would expect the county chair to play a key role. Some partisan differences exist in the activity patterns of county chairs. Republicans were somewhat more active than Democrats. Republican chairs are more likely than Democratic chairs to be involved in organizing campaign events, fund-raising functions, telephone campaigns, and voter registration efforts. Republican chairs also are more likely to spend time dealing with the media. The differences in many cases are not great, but the overall pattern is clear and consistent. 
The same information was obtained in the 1991 survey of North Carolina party activists, and the comparisons with the 2001 results yield several interesting and unexpected findings (Prysby 1992). First, there was an overall increase in reported campaign activity among Democratic activists. In most cases, the increase was small, but on almost every item, more 2001 executive committee members reported engaging in the activity than did the 1991 respondents. However, activity levels for Republican activists in 2001 were fairly similar overall to their 1991 levels, although if we focus on just Republican county chairs, we do find that they are more active in 2001 than they were a decade ago.

Communication patterns within the parties provide another perspective on organizational activity (Brodsky and Brodsky 1998). County chairs naturally report more communication activity than do other grassroots activists, but even these other activists report high levels of communication with the chair and other members of the county executive committee. Moreover, the reported communication activities for 2001 are greater than what was reported in 1991. From this perspective, the local parties have become more active over the past ten years. When it comes to communications with those in the state or national party organizations, chairs are much more active, a pattern that also existed in 1991. Finally, it is worth noting that the party activists report considerable communication with state and local elected officials. This suggests that the local party organizations are connected to the party officeholders and that party officeholders and candidates seek the support of the local activists from their party.

Finally, we can assess party strength by examining the perceptions of the county chairs. County chairs in both parties report that their party organization is stronger now than it was a decade ago. In the case of Republican chairs, these assessments are widespread. Among Democratic chairs, such assessments are more mixed, although more chairs report improvement rather than decline in such key areas as fund-raising ability, development of party workers, use of media, and campaign effectiveness (Prysby 2002b). These perceptions of Democratic county chairs, combined with the modest increases in reported activity among county executive committee members and with the influx of younger activists into the party, contradict the belief held by many that Democratic grassroots organizations are weaker than they were a decade or two ago. Of course, there probably has been a decline relative to Republican county organizations, and the belief about Democratic county organizations may reflect that fact. 


\section{Conclusion}

Both continuity and change characterize grassroots political party activists in North Carolina over the past ten years. These data suggest that grassroots party organizations are as well off as they were a decade ago, at least in terms of the reported behavior of members of the county executive committees. This study does not have data on the number of people who are active in the county party organizations now as compared to a decade ago, so we cannot determine if there has been a change in the number of activists in either party. What we are able to conclude is that those who are members of the county executive committee, including the county chairs, seem as least as involved in a variety of ways as they were ten years earlier.

Furthermore, perceived factionalism is lower, perhaps because the two party organizations have become more cohesive and more distinct ideologically. The greater ideological distinctiveness of the parties exists across a wide range of issues. The fact that the party activists are further apart ideologically suggests that there could be increased tension between candidates and activists. Candidates may be more concerned with appealing to moderate voters in order to win. Activists may be more concerned with energizing core voters. This could be a greater concern for Republican activists, who are a more purist group, motivated more by purposive incentives, and more ideologically extreme. However, Democrats are not immune to this problem, especially when it involves race-related issues.

\section{REFERENCES}

Baker, Tod A. 1990. The Emergence of the Religious Right and the Development of the Two-Party System in the South. In Political Parties in the Southern States, eds. Tod Baker, Charles D. Hadley, Robert P. Steed, and Laurence W. Moreland. New York: Praeger.

Baker, Tod A., Robert P. Steed, and Laurence W. Moreland. 1998. Cultural Wars and Religion in the South: The Changing Character of the Party Struggle. In Party Activists in Southern Politics: Mirrors and Makers of Change, eds. Charles D. Hadley and Lewis Bowman. Knoxville: University of Tennessee Press.

Breaux, David, Stephen D. Shaffer, and Patrick Cotter. 1998. Mass/Elite Linkage. In Party Organization and Activism in the American South, eds. Robert P. Steed, John A. Clark, Lewis Bowman, and Charles D. Hadley. Tuscaloosa: University of Alabama Press.

Brodsky, David, and Simeon Brodsky. 1998. Communication Patterns. In Party Organization and Activism in the American South, eds. Robert P. Steed, John A. Clark, Lewis Bowman, and Charles D. Hadley. Tuscaloosa: University of Alabama Press.

Brodsky, David M., and Patrick R. Cotter. 1998. Political Issues and Political Parties. In Party Activists in Southern Politics: Mirrors and Makers of Change, eds. Charles D. Hadley and Lewis Bowman. Knoxville: University of Tennessee Press. 
Clark, John A., John M. Bruce, John H. Kessel, and William G. Jacoby. 1991. I'd Rather Switch than Fight: Lifelong Democrats and Converts to Republicanism among Campaign Activists. American Journal of Political Science 35:577-597.

Clark, John A., Brad Lockerbie, and Peter W. Wielhouwer. 1998. Campaign Activities. In Party Organization and Activism in the American South, eds. Robert P. Steed, John A. Clark, Lewis Bowman, and Charles D. Hadley. Tuscaloosa: University of Alabama Press.

Feigert, Frank B. and John R. Todd. 1998a. Migration and Party Change. In Party Activists in Southern Politics: Mirrors and Makers of Change, eds. Charles D. Hadley and Lewis Bowman. Knoxville: University of Tennessee Press.

Feigert, Frank B. and John R. Todd. 1998b. Party Maintenance Activities. In Party Organization and Activism in the American South, eds. Robert P. Steed, John A. Clark, Lewis Bowman, and Charles D. Hadley. Tuscaloosa: University of Alabama Press.

Gibson, James L., Cornelius P. Cotter, John F. Bibby, and Robert J. Huckshorn. 1983. Assessing Party Organizational Strength. American Journal of Political Science 27:193-222.

Gibson, James L., Cornelius P. Cotter, John F. Bibby, and Robert J. Huckshorn. 1985. Whither the Local Parties? American Journal of Political Science 29:139-160.

Gibson, James L., John P. Frendreis, and Laura L. Vertz. 1989. Party Dynamics in the 1980s: Change in County Party Organizational Strength, 1980-1984. American Journal of Political Science 33:67-90.

Hadley, Charles D., and Harold W. Stanley. 1998. Race and the Democratic Biracial Coalition. In Party Activists in Southern Politics: Mirrors and Makers of Change, eds. Charles D. Hadley and Lewis Bowman. Knoxville: University of Tennessee Press.

Jackson, John S., III, Barbara L. Brown, and David Bositis. 1982. Herbert McClosky and Friends Revisited: 1980 Democratic and Republican Party Elites Compared to the Mass Public. American Politics Quarterly 10:158-180.

Maggiotto, Michael A. and Gary D. Wekkin. 2000. Partisan Linkages in Southern Politics: Elites, Voters, and Identifiers. Knoxville: University of Tennessee Press.

McGlennon, John. 1998a. Factions in the Politics of the New South. In Party Organization and Activism in the American South, eds. Robert P. Steed, John A. Clark, Lewis Bowman, and Charles D. Hadley. Tuscaloosa: University of Alabama Press.

McGlennon, John J. 1998b. Ideology and the Southern Party Activist: Poles Apart or Reflecting the Polls? In Party Activists in Southern Politics: Mirrors and Makers of Change, eds. Charles D. Hadley and Lewis Bowman. Knoxville: University of Tennessee Press.

Moreland, Laurence W. 1990a. The Ideological and Issue Bases of Southern Parties. In Political Parties in the Southern States, eds. Tod Baker, Charles D. Hadley, Robert P. Steed, and Laurence W. Moreland. New York: Praeger.

Moreland, Laurence W. 1990b. The Impact of Immigration on the Composition of Party Coalitions. In Political Parties in the Southern States, eds. Tod Baker, Charles D. Hadley, Robert P. Steed, and Laurence W. Moreland. New York: Praeger.

Nesbit, Dorothy Davidson. 1988. Changing Partisanship among Southern Party Activists. Journal of Politics 50:322-334.

Prysby, Charles. 1992 Party Organizations in North Carolina. Citadel Symposium on Southern Politics, 1992. 
164 | Charles Prysby

Prysby, Charles. 1995. North Carolina: Emerging Two-Party Politics. In Southern State Party Organizations and Activists, eds. Charles D. Hadley and Lewis Bowman. Westport, CT: Praeger.

Prysby, Charles. 1997. North Carolina. In State Party Profiles, eds. Andrew M. Appleton and Daniel S. Ward. Washington, DC: CQ Press.

Prysby, Charles. 1998. Purist versus Pragmatic Orientations. In Party Organization and Activism in the American South, eds. Robert P. Steed, John A. Clark, Lewis Bowman, and Charles D. Hadley. Tuscaloosa: University of Alabama Press.

Prysby, Charles. 2002a. North Carolina: Continued Two-Party Competition. In The 2000 Presidential Election in the South, eds. Laurence W. Moreland and Robert P. Steed. Westport, CT: Praeger.

Prysby, Charles. 2002b. North Carolina: The Development of Party Organizations in a Competitive Environment. Citadel Symposium on Southern Politics.

Roback, Thomas H. 1975. Amateurs and Professionals: Delegates to the 1972 Republican National Convention. Journal of Politics 37:436-468.

Soule, John W., and James W. Clarke. 1970. Amateurs and Professionals: A Study of Delegates to the 1968 Democratic National Conventions. American Political Science Review 64:888-898. 